\title{
訂正 Errata
}

1989, J. Yamashina Inst. Ornith Vol. 21 No. 2 (No. 82)

\begin{tabular}{|c|c|c|c|c|}
\hline & 誤 & & 正 & \\
\hline 口絵 & P. $2 \longdiv { \text { 上 } }$ & 須 賀 子 & $\rightarrow$ & 寿 賀 子 \\
\hline$"$ & P. 3 上 & " & $\rightarrow$ & " \\
\hline$"$ & P. 3 下 & 岸田千代 & & 岩田千代 \\
\hline P. 144 & 4 L. 3 & 須 賀 子 & $\rightarrow$ & 寿 賀 子 \\
\hline P. 224 & 4 L. 14 & Condluded & - & Concluded \\
\hline P. 309 & 9 L. 9 & Anvironment & $\rightarrow$ & Environment \\
\hline
\end{tabular}

1991. J. Yamashina Inst. Ornithol. Vol. 22. No. 1 (No. 83)

\begin{tabular}{|c|c|c|c|}
\hline P. 1 & 下 2 & Aprfi & $\rightarrow$ April \\
\hline P. 9 & 下 4 & accepred & $\rightarrow$ accepted \\
\hline P. 65 , & 66 & Fig. 4 の図 & 欠面の Fig. 5 の図が这 \\
\hline P. 70 & 下 3 & and を取己 & \\
\hline P. 71 & . 12 & "Criental & $\rightarrow$ “Oriental \\
\hline P. 73 & $上 15$ & incabation & $\rightarrow$ incubation \\
\hline P. 73 & 上 18 & theworld's & -. the world's \\
\hline
\end{tabular}

